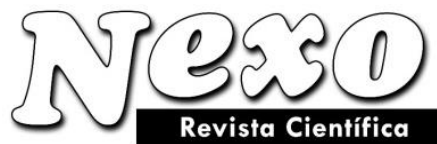

ISSN-E 1995-9516

Universidad Nacional de Ingeniería COPYRIGHT @ (UNI). TODOS LOS DERECHOS RESERVADOS http://revistas.uni.edu.ni/index.php/Nexo https://doi.org/10.5377/nexo.v34i04.12653

\title{
Legal regulation of rational energy production and consumption in Russia and other states
}

\section{Regulación legal de la producción y el consumo racional de energía en Rusia y otros estados}

\author{
Evgeniy E. Tonkov ${ }^{1}$, Vladislav Yu. Turanin ${ }^{1, *}$, Oksana S. Lilikova ${ }^{1}$, Marina M. Staroseltseva ${ }^{2}$, \\ Elena A. Gorshkova ${ }^{3}$ \\ ${ }^{1}$ Belgorod National Research University (85 Pobedy Street, Belgorod, 308015 Russian \\ Federation) \\ ${ }^{2}$ Putilin Belgorod Law Institute of Ministry of the Interior of Russia, (71 Gorky Street, Belgorod, \\ 308024, Russia Federation) \\ ${ }^{3}$ Moscow Politechnic University (38 B.Semenovskaya street, Moscow, 107023 Russian \\ Federation Russia) \\ *Turanin@bsu.edu.ru
}

(recibido/received: 15-mayo-2021; aceptado/accepted: 10-agosto-2021)

\begin{abstract}
The authors of the article analyze the problems of legal regulation of rational subsoil use and energy consumption in Russia, Germany, USA, Japan and other countries. It also compares the energy legislation of different countries. Based on the results, it was concluded that the development of the legislation of these countries is in general compliance with the strategic goals in the field of energy production and consumption. These goals are the construction of ecologically clean "green" energy based on the rational use of mineral resources and minerals and the rational and efficient distribution of energy.
\end{abstract}

Keywords: legal regulation, energy production, energy consumption, rational energy consumption, energy law.

\section{RESUMEN}

Los autores del artículo analizan los problemas de la regulación legal del uso racional del subsuelo y el consumo de energía en Rusia, Alemania, Estados Unidos, Japón y otros países. También compara la legislación energética de diferentes países. Con base en los resultados, se concluyó que el desarrollo de la legislación de estos países está en cumplimiento general con los objetivos estratégicos en el campo de la producción y consumo de energía. Estos objetivos son la construcción de energía "verde" ecológicamente limpia basada en el uso racional de los recursos minerales y minerales y la distribución racional y eficiente de la energia. 
Palabras clave: regulación legal, producción de energía, consumo de energía, consumo racional de energía.

\section{INTRODUCTION}

Despite the fact that Russia is an advanced country in the field of energy and is one of the important importers of energy, the legal essence of Russian energy law is a controversial issue. This industry is a set of legal norms governing relations in the field of production, transmission, distribution, consumption of energy. Also, these are relations related to the coal, gas, oil industry, nuclear energy.

P.G. Lakhno considers energy law to be a complex industry capable of expressing both private law (the opinion of an individual) and public law interests (the interests of the entire state and society are represented) (Lahno, 2014). F. Yu. Zekker expresses that energy business law, for example, can be attributed to public law, and energy consumer protection law or cartel law can be classified as private law (Zekker, 2008).

\section{METHODS}

The work uses various general scientific techniques and methods of logical cognition: analysis and synthesis, systemic, functional and formal-logical approaches. Formation of conclusions was facilitated by the use of formal legal and comparative legal methods.

\section{RESULTS AND DISCUSSION}

When implementing regulation in the field of energy use, first of all, it is necessary to be guided by international legal principles. It is very important to coordinate the work and unify the legislation of the participating countries. This is necessary in order to protect the environment, consistent and safe energy production and rational use of resources.

International standards as sources of energy law include the Agreement on Partnership and Cooperation between the Russian Federation, the European Community and its Member States in June 24, 1994, according to which cooperation was supposed in the field of entrepreneurial activity, the establishment of competition rules, the field of nuclear energy, environmental protection. The agreement was ratified and entered into force on December 1, 1997 for 10 years with subsequent prolongation. Its participants are the European Union and all countries of the Commonwealth of Independent States (Tajikistan did not participate). As stated in paragraph 2 of Article 65 of the Agreement, cooperation includes, among other things, the following areas: development of energy policy, development of energy saving and energy efficiency, it also includes the improvement of infrastructure in the energy sector, taking into account electricity and gas supply.

Article 66 of the same Agreement contains a provision on nuclear power, which provides for civil cooperation and the implementation of the rules of the agreement on thermonuclear fusion and nuclear safety to be concluded by the parties to the Partnership and Cooperation Agreement. 
In 1995, the Energy Charter and the Energy Charter Treaty were signed, which contained transit, trade and investment provisions (Vasilyeva, 2017). These documents were fundamental provisions prior to the 2009 Ukrainian-Russian conflict over gas. For this reason, a new project was developed in 2010 - the Convention on Ensuring International Energy Security, the Protocol to the Convention and the Doctrine on Energy Security. Of the significant differences between the new international treaties, one can single out the division of countries into suppliers and consumers of energy resources, and a category of transit states is highlighted. Most of the provisions were borrowed from the 1994 Agreement, however, the new document introduced responsibility for global energy security.

Strategic legal documents have a great influence on the Russian legal regulation of rational energy consumption.

The Energy Strategy of Russia for the period up to 2030 (Lezier et al., 2017) not only defines the main strategic guidelines, but also provides the expected results and a system for implementing the Strategy, and developed a consolidated plan («road map») of state energy policy measures. This document also concerns the sphere of subsoil use, in the area of which the strategic goal is to ensure sustainable, efficient and environmentally safe reproduction of the mineral resource base. To achieve the stated goal, the tasks and measures and mechanisms of the state energy policy are defined in detail and concretized, and the "road map" contains measures. For example, among the measures to stimulate effective subsoil use based on the full and comprehensive extraction of hydrocarbons from the subsoil at the third stage (2023-2030), tax incentives are provided for the expanded production of super-viscous oil, natural bitumen, low-pressure gas from old fields and the integrated use of resources from coal deposits, including projects for the utilization of degassing methane. Of course, it should be noted that in order to implement the Fundamentals of State Policy in the Field of Environmental Development of the Russian Federation, an Action Plan was adopted (Vasilyeva, 2017), but it cannot be considered perfect. «Unfortunately, in our opinion, the Action Plan lists items that do not quite reflect the goals and objectives of the Fundamentals of State Policy in the Field of Environmental Development of the Russian Federation, both in content and in spirit (idea)» (Lezier et al., 2017).

If we talk directly about the sphere of rational subsoil use and energy consumption, then there is no generalizing comprehensive strategic document in this area. There is the aforementioned Energy Strategy, which deals with the issues of rational extraction of energy resources, and there is the Strategy for the development of the mineral resource base of the Russian Federation until 2035 (Voskresenskaya et al., 2018), which also applies to the field of mining. In this document, the priority of the Russian Federation in the development of the mineral resource base for the long term is the formation of an economically sound balance between necessary and sufficient domestic consumption, export and forced import of mineral raw materials, which is achieved through timely reproduction and rational use of mineral reserves. One of the tasks is to ensure the rational use of the created mineral resource base by bringing into operation hard-to-recover oil and gas reserves, undeveloped deposits of solid minerals, creating conditions for the development of man-made deposits, extracting valuable components from overburden, enclosing rocks, as well as associated industrial waters. As you can see, both strategies are balanced with each other and generally reflect, in terms of mining, the general directions of economic activity in this area. The Fundamentals of State Policy in the Use of Mineral Raw Materials and Subsoil Use (Voskresenskaya et al., 2018) are also in force, in which one of the three main goals of the state 
policy in the field of the use of mineral raw materials and subsoil use is the organization of rational and comprehensive use of mineral resources in the interests of present and future generations of Federation.

Among the measures aimed at the rationality of subsoil use was named the stimulation of the use of the best technologies for exploration and production of minerals, minimization of the negative impact on the environment during exploration and mining; expanding the participation of small and medium-sized businesses in activities in the field of the use of mineral raw materials and subsoil use.

The issues of rational energy consumption are the subject of regulation not only in Russian law, but also in the legislation of other states.

Take, for example, a country where energy law has developed at a high level - Germany. Its peculiarity is that there are no huge reserves of resources on the territory of the country, including oil and gas, so Russia is a major importer for it. The Federal Republic of Germany is one of the countries with a high percentage of GDP and the sixth country in terms of energy consumption.

At the moment, Germany is concerned about the introduction of renewable energy sources. There is a question of finding an alternative for known resources, since deposits, for example, oil, are excisable. In addition, it is also the fulfillment of the task of protecting the environment. In Germany, energy law is an independent branch of law, has its own subject and method of regulation.

There are four sources of law that govern these relationships. Firstly, it is the Law on Guaranteed Electricity and Gas Supply. It has been operating since 1975 throughout the country. Secondly, in 1935 the Law on Energy Economy was adopted, which was in force for 63 years, and only in 1998 was the new Law on Energy Economy adopted. In 2003 and 2005, significant changes were made to it. The reason for the adoption of the new regulation was the Europeanization of energy legislation. In this law, the author defines the long-term perspective of further reliable power supply. A federal grid operations agency is expected to be set up to resolve disputes over access to transmission grids. Disputes over payment for these services will also be resolved (Roggenkamp, 2001). It is believed that this law creates the basic conditions for Germany to attract a huge number of investments in the energy sector. It is also important that the document separates network operation and energy production. This is done in order to ensure a level playing field for the subjects of competition.

Antitrust and contract laws have a particular impact on energy law. Also, it can be said that at the heart of these four sources is still the law of environmental protection.

At that time, during the adoption of these laws, the issue of creating a single energy market was being decided, the goal was to reduce electricity prices, increase competition between enterprises. We can say that these factors contributed to the creation of the European Union.

European energy legislation has been striving for harmonization since 1996, when Directive 96/92/EC on the internal electricity market was adopted. Following Directive 98/30/EC, the harmonization of the European natural gas market began (Aalto, 2016). 
Strong changes in the energy sector emerged with the coming to power of the «red-green» coalition within the Social Democratic Party of Germany. When the Green Party gained power, became ruling, plans began to be implemented to change the course of development of the energy sector in the country. The main change was considered the refusal to use nuclear energy. In 2001, the relevant documents were signed, indicating a ban on the construction of new nuclear power plants, as well as a refusal to extend the operation of existing ones. In addition, the authorities have imposed a ban on the reprocessing of nuclear fuel (Voskresenskaya et al., 2018).

As a result of these changes, Germany would cease to act as an importer of nuclear fuel and would not spend on its expensive reprocessing in the UK and France. Prior to the adoption of all important decisions in Germany, nuclear and nuclear power accounted for $30 \%$ of the total share of production. After that, the emphasis was placed on the consumption of electricity. In accordance with the law, special tariffs were established depending on the type of energy. According to them, producers of renewable energy sources returned 5-10\% over 20 years.

Back in 2007, the German authorities abandoned coal mining until 2018, which was due to the high cost. A ton of coal cost 200 euros, which is more than three times higher than the prices on the world market. This decision was considered economically more profitable - to replace German coal with imported from Russia, Canada and Australia.

At the moment, European energy law is a system that distinguishes national energy law, based on the geographical characteristics of the area and the resource reserve of an individual European country, and European energy law, which considers European countries as a whole.

It is impossible not to pay attention to the US energy legislation, which entered a new vector of development since the early 1970s and 1980s, which is associated with the adoption of the federal law «On National Energy» (National Energy Act — NEA). This act became the first basic and fundamental Law, which included norms regarding the regulation of all relations arising, changing and terminating with regard to the production and distribution and redistribution of energy resources (Belyaeva et al., 2020). He was able to define the national energy policy and build the necessary strategy. In addition, particular importance is emphasized by the fact that the United States is a state with a federal form of government, and before that there was no general government, since regulation in each of the states took place only at the «regional» level and became the basis for a new act.

The structure of energy law as an industry in the United States is a set of public relations regulated by the rules of energy law and related to it, divided into the following industries: oil industry, gas industry, coal industry, electric power industry, nuclear energy and hydropower. In addition, the system also introduces legal regulation of clean energy sources and renewable energy sources (Turanin et al., 2020).

The energy policy is mentioned in the US National Security Strategy, which was adopted in November 2017. The text states that "for the first time in its history, the United States will be the dominant energy power. Energy dominance is America's central position in the global energy system as a leading producer, consumer, and innovator - ensuring that markets are free and that US infrastructure is stable and secure. The resumption of the development of energy resources - 
coal, natural gas, oil, renewables and nuclear energy - will create the basis for future growth» (National Security Strategy of the United States of America. December 2017).

Among the states that have achieved tremendous success in the field of energy conservation, Japan occupies an exceptional place, due to the specifics of the country's economic development, historical aspects that influenced the recovery in the post-war period (rapid growth in energy consumption, lack of its own raw materials, dependence on imports).

The basic legislative act in the field of energy conservation is the Law on Rational Use of 1979. Initially, its main goal was to ensure an effective energy saving policy in the industrial sector of the economy: rationalizing the use of fuel, contributing to effective economic development through measures to revise energy consumption in enterprises, offices and residential premises, including measures affecting the introduction of special types of equipment. This law has been revised several times (1993, 1998, 2008 and other years). The specificity of this law is that the main emphasis in its application in practice is focused on positive motivation, and not on the imperative and fear of being punished. It is understood that energy consumers will intelligently enforce the requirements of the law and adhere to those requirements that were set by the state through the overall «ideological» goal - the formation of an energy-saving and competitive economy. In addition, a similar approach consists in achieving, in the course of such development, innovations with the help of which the opportunity to defeat "rivals" in market competition was more likely.

\section{CONCLUSION}

Each state has a different set and amount of resources, as a result of which special legislation is formed that differs from other countries.

Having analyzed the legislation of different countries, it can be concluded that the «models» of the law on energy resources of each state are different. One can distinguish the American "codification" model, the "general principle" model (for example, the Korean Basic Energy Law), and the "political model" that establishes an energy strategy and unified policy (for example, the Japanese Basic Energy Policy Law). Of particular importance is the focus on the internal characteristics of the state, taking into account the provisions on environmental protection and minimization of harm caused by production, as well as the possibility of using certain technologies. Activities in the energy sector are inherently associated with risks, in this regard, it is important not only to determine the scope of what is permitted, to establish a clear procedure, but also to establish measures of responsibility in case of violation of the established rules and requirements.

Russia has an incomparable reserve of energy resources, unlike a number of countries in Europe and America, therefore its legislation on subsoil use differs from foreign legislation. At the same time, taking into account the global economic ties in the field of energy, one can state that the goal-setting in the field of rational energy consumption in various countries (including Russia) corresponds to world trends, which can be summarized as «green energy». The generally recognized principles and norms of international law and international treaties of the Russian Federation are an integral part of its legal system, which is an important fact when building a strategy for the development of Russia in the field of rational energy consumption. Cooperation 
with advanced countries makes it possible to more effectively rationalize the use of natural resources, which should be given special attention. As noted by P.L. Kapitsa, the future of the Russian energy sector depends to a large extent on the correctness of the construction of legal regulation of this branch of law.

With the correct analysis of foreign experience, the development of export agreements and the constant exchange of the results of the work done, the rationality of energy consumption will become even more important both in Russia and on the world stage.

\section{CONFLICT OF INTEREST}

The authors confirm that the information provided in the article does not contain a conflict of interest.

\section{REFERENCES}

Aalto, P. (2016). The new International Energy Charter: instrumental or incremental progress in governance? Energy Research \& Social Science, 11, 92-96.

Belyaeva, G. S., Katomina, V. A., Kutina, V. P., Khabiyeva, Z. D., \& Podolskiy, A. V. (2020). Legal Regime and Stages of Procedural Regulation: Essence and Content. Revista TURISMO: Estudos e Práticas, (3).

Lahno, P.G. (2014). Energy law of the Russian Federation: formation and development [Energeticheskoe pravo Rossijskoj Federacii: stanovlenie i razvitie]. Moskva: Izd-vo MGU im. M.V. Lomonosova. 480 p. (in Russian)

Lezier, V., Gusarova, M., \& Kopytova, A. (2017). Energy management in modern Russia: problems, development trends, prospects. In IOP Conference Series: Earth and Environmental Science (Vol. 90, No. 1, p. 012034). IOP Publishing.

National Security Strategy of the United States of America. December 2017 [Electronic resource]. National Security Strategy Archive. URL: http:// nssarchive.us/wp-content/uploads/2017/12/2017.pdf (date of request: 30/09/2020).

Roggenkamp, M. (2001). Energy Law in Europe: National, EU and International Law and Institutions. Oxford: Oxford University Press. 1267 p.

Turanin, V. Y., Yarychev, N. U., Senyakin, I. N., Sumenkov, S. Y., \& Vasekina, E. M. (2020). MEANS OF LEGAL TERMS SYSTEMATIZATION IN LAWMAKING. Revista TURISMO: Estudos e Práticas, (2).

Vasilyeva, E. (2017). Formation of Conceptual Provisions for the Development of the Energy Efficient Housing Construction in Russia. In IOP Conference Series: Earth and Environmental Science (Vol. 90, No. 1, p. 012216). IOP Publishing.

Voskresenskaya, E., Mokhorov, D., \& Tebryaev, A. (2018). Ecological state of the urban environment as an object of forensic analysis within the period of introducing the judicial reform of Russia. In Matec web of conferences (Vol. 170, p. 01057). EDP Sciences.

Zekker, F.YU. (2008). Guiding Ideas and Sources of Energy Business Law [Rukovodyashchie idei i istochniki energeticheskogo hozyajstvennogo prava. Energetika i pravo]. Moskva. 234 p. (in Russian) 